\title{
INSTITUTIONAL FRAMEWORK FOR REGIONAL INTERNATIONAL SCIENTIFIC AND TECHNICAL COOPERATION IN THE SCO AND ASEAN
}

\author{
Adel I. Abdullin ${ }^{1}$ \\ Rosa I. Sitdikova ${ }^{2}$ \\ Natalia E. Tyurina ${ }^{3}$ \\ Liliia D. Iafizova ${ }^{4}$
}

\begin{abstract}
This article presents a comprehensive analysis of the institutional forms of regional scientific and technical cooperation in such integration associations as the SCO and ASEAN. The founding documents of the SCO (the Charter of the Shanghai Cooperation Organization) and ASEAN ( $\mathrm{n}$ the Declaration on the Establishment of ASEAN) define scientific and technical cooperation as one of the tasks of these regional organizations. The authors proceed from the fact that overcoming the obstacles to the development of modern society is unthinkable without reliance on scientific and technological progress, and therefore a joint search for solutions
\end{abstract}

to problems that already exist today and may arise in the $21 \mathrm{st}$ century is necessary. The expansion of cooperation in the field of science and technology within the framework of the SCO has been defined as one of the areas of cooperation and an institutional mechanism for the interaction of member states has been created, in which a permanent working group on scientific and technical cooperation holds an important place. One of the significant results in creating the material base for joint research is the SCO University (SCOU). Its main goal is to give a new impetus to the expansion of multilateral educational, scientific and cultural cooperation. The article notes that

\footnotetext{
${ }^{1}$ Kazan Federal University. e-mail: interlaw.kpfu@gmail.com. Tel.: +7(843) 2337101.

${ }^{2}$ Kazan Federal University. e-mail: interlaw.kpfu@gmail.com. Tel.: +7(843) 2337101.

${ }^{3}$ Kazan Federal University. e-mail: interlaw.kpfu@gmail.com. Tel.: +7(843) 2337101.

${ }^{4}$ Kazan Federal University. e-mail: interlaw.kpfu@gmail.com. Tel.: +7(843) 2337101.
} 
ASEAN's scientific and technical research is not limited to internal projects. A significant role in the development of this area is played by documents and institutions in which Russia is involved.

Keywords: international regional cooperation, scientific and technical cooperation, Shanghai Cooperation Organization, Association of Southeast Asian Nations.

The reported study was funded by RFBR according to the research project № 18-29-15046.

\section{Introduction}

Scientific and technical cooperation in the modern world is becoming an integral part of interstate relations. In this regard, the legal and political lexicon acquires a new concept - scientific diplomacy. The essence of this concept is revealed in the activities of international institutions, which are most characteristic of relations at the regional level [1] [2].

Since the exchange of scientific knowledge and discoveries is of great interest to Russia, the study of the legal aspects of the activities of international regional organizations in this area is a necessity in order to use and optimize the methods and forms of research cooperation to increase the country's scientific potential.

\section{Methods}

An analytical study of regional scientific cooperation using a formal legal and comparative method revealed the experience of institutional interaction within the framework of regional international organizations, which can be used to further develop and improve joint research and technological developments. At the same time, special attention is paid to auxiliary, nonetheless essential, instruments of legal regulation, including, inter alia, provisions on the status of a joint project.

\section{RESUlts AND DiscuSSION}

Based on the special attention that is currently being paid in Russia to the development of relations with the countries of the Asian region, the proposed article will consider scientific cooperation in the SCO and ASEAN. 


\section{Shanghai}

\section{Cooperation}

Organization (SECO). Publications devoted to this organization mainly focus on security issues, to a lesser extent - on economics, and almost neglect the sphere of scientific and technical relations [3]. Meanwhile, the experience of cooperation in this area exists and is of interest from the point of view of institutional interaction.

The SCO's founding document

- the Charter of the Shanghai Cooperation Organization - encourages scientific and technical cooperation as one of the tasks, the solution of which is defined as the goal of this institution. In addition, given that overcoming obstacles to the development of modern society is unthinkable without reliance on scientific and technological progress, a joint search for solutions to problems that will arise in the 21 st century can be noted as a task of this kind. The expansion of cooperation in science and technology is also defined as one of the areas of cooperation within the SCO [4].

In May 2010, the first meeting of the heads of ministries and departments of science and technology of the SCO member states was held in
230

Beijing, at which it was decided to create a permanent working group on scientific and technical cooperation. The working group is called upon to promote the expansion of scientific and technical cooperation between the SCO member states and improve the legal framework of relations in this area.

An important stage in the formation of the legal framework was the signing of the Agreement on scientific and technical cooperation on September 13,2013 [5].

Article 1 of the Agreement provides a list of areas of cooperation that defines areas of research; it is worth noting that this list is not exhaustive.

Forms of cooperation in accordance with Article 2 of the Agreement may be:

- organization of scientific and technical research;

development and implementation of joint scientific and technical programs and projects;

- organization and participation in scientific conferences, seminars and 
other events held within the framework of the SCO;

development and implementation of innovative technologies in various fields of science; - exchange of scientific and technical information;

- exchange of experts and scientists;

- other possible forms determined by the Parties by mutual agreement.

Coordination of cooperation on the implementation of the provisions of the Agreement was entrusted to a permanent working group on scientific and technical cooperation (Article 5).

In terms of legal regulation, the Agreement acts as a general basis for interaction in all these areas. For the implementation of certain provisions the signing of individual protocols is provided (Article 6) [5].

In order to implement the Agreement in general, the Council of Heads of Government took a decision on a plan of practical measures (roadmap) for cooperation between research institutions of the SCO member states for 2019-2020. The plan aims to expand the scope of scientific and technical cooperation through the exchange of innovations, research results and is focused on the creation of large-scale joint research programs. Particular emphasis is placed on partnerships between scientific organizations, scientists and specialists of the SCO member states, joint work on the practical implementation of ideas, projects and innovative solutions, participation in international symposia, conferences, seminars and other events in the field of science and technology [6].

A number of these activities are carried out within the framework of the SCO Forum, which was established on May 22, 2006. The Forum Regulations (Article 1.2) determine that it is a multilateral, public consultation and expert mechanism established to facilitate and provide scientific support to the activities of the SCO and to develop scientific cooperation - research and political science centers of the SCO member states, conducting joint research on topical issues of the terms of reference of the Organization, explaining the tasks and principles of the SCO, expanding its ideology with scientific and public circles, as well as 
encouraging exchanges of opinions between scientists and experts in the fields of politics, security, economics, ecology, new technologies, in the humanitarian and other fields [7].

Over the past years, the Forum has established itself as an authoritative scientific and analytical event, in the framework of which discussions are unfolding on the most pressing political and economic issues. More than 100 scientists, experts and diplomats from member states, observer countries and SCO dialogue partners took part in the annual meeting of the Forum held on April 17-18, 2019, organized by the Chinese Academy of International Affairs at the Ministry of Foreign Affairs of the PRC. The topic of the scientific reports of this meeting was continued, in particular, the study of such an urgent problem of international law in relation to the Eurasian region as integration processes.

One of the significant results in creating the material base for joint research is the SCO University (SCOU). The university operates on the basis of 53 universities in the SCO member states, as well as observer countries without the formation of an independent legal entity. Among the goals of the SCO is to give a new impetus to the expansion of multilateral educational, scientific and cultural cooperation, and provides, inter alia, the harmonization of forms and main topics of coordinated research [8].

Joint scientific research and the exchange of achievements in this area constitute a promising area in the relations of the SCO member countries. This is confirmed by the Development Strategy of the Shanghai Cooperation Organization until 2025, which provides for the consistent expansion of relations between educational, scientific and research institutions, the implementation of joint research programs and projects of mutual interest [9].

\section{Association of Southeast} Asian Nations (ASEAN). Features of scientific and technical cooperation in ASEAN were considered in a number of foreign publications, but have not yet received comprehensive coverage from domestic researchers [10]. The institutional aspect that is the subject of this article is intended to partially fill this gap. 
The Declaration on the Creation of ASEAN (Bangkok Declaration, August 8, 1967) defines scientific and technical cooperation as one of the tasks of this regional organization [11]. Subsequently, this provision of the Declaration was reproduced in the Treaty of Friendship and Cooperation in Southeast Asia (Bali Treaty, Indonesia, February 24, 1976), to which Russia, which is not a member of ASEAN, acceded on November 29, 2004. In the treaty (Article 8 ) it is specified that the parties will provide each other with materials for training and research in the social, cultural, technical, scientific and administrative fields [12]. Thus, for the purposes of the study, not only the interaction of ASEAN members but also the relations of this organization in the field of scientific and technical cooperation with Russia and the EAEU are of great interest.

For several decades, ASEAN focused primarily on resolving economic problems. Certain successes achieved in this area allowed us to move on to other issues that were raised in the constituent document. In 1978, the Science and Technology Committee (STC) was formed. STC coordinates scientific and technical cooperation in ASEAN under the leadership of the Ministerial Conference on Science and Technology. The Consultative Council, 9 subcommittees in various areas of scientific and technical research and an expert group on metrology operate within the framework of the STC. STC also acts as the central body for relations with relevant authorities in individual countries and regional organizations, with which ASEAN has a partnership dialogue. These include Russia.

STC is also responsible for the distribution and use of the proceeds of the ASEAN Science and Technology Foundation (Science Foundation), which was established to finance programs, projects and activities in the field of scientific and technological cooperation. The determination of the strategy and the consideration of funding requests takes place with the assistance of the Advisory Board. On April 8, 2000, ASEAN member countries signed an Agreement to increase the Science Fund by establishing a contribution of one million US dollars for each ASEAN member [13].

Currently, the main activity of the STC is the strategic guide for the 
implementation of the Action Plan in the field of science, technology and innovation for 2016-2025 (hereinafter referred to as the Action Plan) [14], which was proposed at the Ministerial Meeting on Science and Technology in November 2015 and adopted on October 26, 2016. The Action Plan is accompanied by an implementation plan that outlines the priority and specific actions established by the nine work plans subcommittees of the STC.

ASEAN scientific and technical research is not limited to internal projects. A significant role in the development of this area is played by documents and institutions Russia is involved in. The Russia-ASEAN Partnership Dialogue (Partnership) was launched in 1996. The forms of joint work within the framework of the Partnership are research projects, scientific conferences, and training programs. The leading role in the development of Partnership projects is played by the Working Group on Scientific and Technological Cooperation (WGSTC). At the first session of the WGSTC, which was held in Moscow on June 9-10, 1997, in the documents adopted in order to regulate its activities, cooperation was named the priority tasks of this institute in the field of science and technology, including biotechnology, new materials, information technology, microelectronics, meteorology and geophysics. Creating favorable conditions for the development of science is provided for by the Agreement between the governments of ASEAN member states and the government of the Russian Federation, concluded in December 2005.

In the current period of time, the Comprehensive Plan of Action for the Development of Cooperation between the Russian Federation and the Association of Southeast Asian Nations (2016-2020) is highly relevant. A separate section is dedicated to science, technology and innovation in this document, which provides for the promotion of mutually beneficial scientific and technological research and exchanges between the Russian Federation and ASEAN member states, as well as the exchange of scientific and technological information; facilitating the participation of representatives of each other, including scientists and experts, in scientific and technological 
conferences, seminars and other international events on issues of science and technology [15].

ASEAN's cooperation with Russia continued in relations between ASEAN and the EAEU, which began in 2014 and seems to be promising (the Memorandum of Understanding between the ECE and ASEAN was signed in Singapore on November 14, 2018) and mutually beneficial in a number of areas, including scientific technical research. Since ASEAN countries constitute one of the centers of technological development in the AsiaPacific region, partnership with ASEAN in the EAEU can provide an additional resource for the technological modernization of the economies of the EAEU member countries. For ASEAN, this is an expansion of opportunities for implementing the Comprehensive Action Plan.

\section{SUMMARY}

The documents adopted by the SCO members on research provide the necessary legal and organizational basis for the development of cooperation in this area at the level of nongovernmental entities and determine the strategic directions of the research institutions of the respective states. At the same time, the solution to the problems posed requires intra-state measures, in particular, coordination of scientific relations with the SCO member states from a single national center. To create and operate such an institution, the experience of the PRC can be used, where a Central Asian scientific and technical center is established through which the SCO member countries can cooperate with all regions of the PRC.

Based on the forms of interaction between the SCO countries, we can distinguish the following components of the regional model in the field of scientific and technical cooperation:

- the legal basis in the form of a constituent act of the organization and a special agreement;

- a specialized body to promote cooperation and improve the legal framework;

- a plan of practical measures (roadmap) for the cooperation of research institutions of the organization's member states;

- consultation and expert forum; 
- a scientific and educational institution based on national universities; - national centers for coordination of cooperation.

The course set by ASEAN and the EAEU for Comprehensive Regional Economic Partnership (CREP) will inevitably require the creation of new institutions of interaction in order to solve the problems of cooperation, including conducting research. Although the mechanisms of ASEAN-EAEU cooperation are not yet sufficiently developed, it can be stated that regional ties at the present stage are no longer limited to the framework of a separate organization. A new format of regional relations is emerging, which covers at least two interstate associations, and therefore opens up a new perspective in the study of the problem considered in this paper.

\section{Conclusions}

The study of regional scientific and technical cooperation on the example of only two regional international organizations shows a wide variety of forms and practices of interaction in this area. Being at different stages of the formation of the research space, the considered organizations are characterized by various approaches and tools used for its formation and effective functioning. In this regard, the development of an optimal model of cooperation requires studying the results achieved in this area, which sets the direction for continuing work on this topic.

\section{Acknowledgments}

The work is performed according to the Russian Government Program of Competitive Growth of Kazan Federal University. The reported study was funded by RFBR according to the research project № 18-29-15046

\section{References}

Mirjana Ćujić. Science Diplomacy and S\&amp; $T$ Collaboration in Serbia// Southern Perspectives on Science and Technology Cooperation. ITEC Programme on Science Diplomacy. New Lehli, RIS, 2019. P. 1-4.

Umawatee Bungaroo Ramdoo. Science Diplomacy and Regional Integration: 
The Eastern and Southern African Experience // Southern Perspectives on Science and Technology Cooperation. ITEC Programme on Science Diplomacy. New Lehli, RIS, 2019. P. 107-112.

Alyson J. K. Bailes, Pál Dunay, Pan Guang, Troitskiy Mikhail. The Shanghai Cooperation Organization SIPRI Policy Paper No. 17. Stockholm International Peace Research Institute, 2007 // https://docviewer.yandex.ru/view/89404 276/ (accessed date 13.06.2019).

Charter of the Shanghai Cooperation Organization (as amended on June 15, 2006), Art. 1, 3) // http://docs.cntd.ru/document/90185889 6 (accessed date: 27.05 2019).

Agreement on scientific and technical cooperation, September 13, 2013 // http://docs.cntd.ru/document/49907415 1 (accessed date: 30.05.2019).

Rashid Alimov: SCO Lokomotiv is confidently following the development path // Shanghai Cooperation Organization.

URL: http://rus.sectsco.org/news/20181012/47 $\underline{1726 . h t m l}$ (access date: 27.05.2019).

Analytical reports of the Scientific Coordination Council for International Studies of the MGIMO (University) of the Ministry of Foreign Affairs of Russia Issue 3(18) // MGIMO University. URL: https://mgimo.ru/files2/y01_2012/2186 50/ad-18.pdf (accessed date: 30.05.2019).

SCO University Concept, October 24, 2008 as amended. September 23, 2010 // http://studyabroad.mpei.ru/rus/USHOS/ uscoConcept/Pages/default.aspx (accessed date: 30.05.2019).

Development Strategy of the Shanghai Cooperation Organization until 2025 // http://static.kremlin.ru/media/events/file s/ru/a3YPpGqLvQI4uaMX431MkrMbF NewBneO.pdf (accessed date: 30.05.2019).

Schüller M., Gruber F., Trienes R., Shim D. International Science and Technology Cooperation Policies of South East Asian Countries// https://www.zsi.at/attach/ConsultationP aper.pdf (accessed date 13.06.2019). 
The Asian Declaration (Bangkok

Declaration) Bangkok, 8 August 1967 //

https://asean.org/the-asean-declaration-

bangkok-declaration-bangkok-8-august-

1967 (accessed date 5.06.2019).

Agreement on friendship and cooperation in Southeast Asia (as amended on July 23, 2010) // http://docs.cntd.ru/document/90228931

$\underline{3}$ (accessed date 05.06.2019).

Agreement on the Augmentation of the ASEAN Science Fund, Genting Highlands, April 8, 2000// https://docviewer.yandex.ru/view/89404 276/ (accessed date 11.06.2019).

ASEAN Plan of Action on Science, Technology and Innovation (APASTI) 2016-2025//

https://asean.org/storage/2017/10/01-

APASTI-2016-2025-FINAL.pdf (accessed date 11.06.2019).

Comprehensive Action Plan for the Development of Cooperation between the Russian Federation and the Association of Southeast Asian Nations (2016-2020)
//

file:///C:/Users/1/Downloads/Comprehe nsivePlanOfAction_RUS\%20(5).pdf (accessed date 05.06.2019) 